Richard Parry

DOI: http://dx.doi.

org/10.18820/24150479/

aa50i2.10

ISSN:0587-2405

e-ISSN: 2415-0479

Acta Academica $\cdot 2018$ 50(2):

148-151

(c) Creative Commons With Attribution (CC-BY)

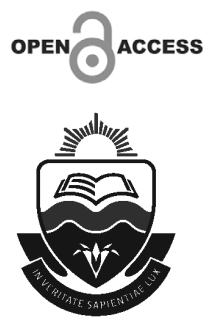

Book review

\section{Reverse sweep: a story of South African cricket since apartheid}

\section{By Ashwin Desai. Auckland Park: Jacana Media, 2017}

This passionate and perceptive book maps the politics of South African cricket from isolation through to transformation, in the light of competing political priorities. Ashwin Desai's enthusiasm for the game itself and its players, and his commitment to political and economic change, shine clearly through this hard-hitting and sometimes controversial narrative. Reverse Sweep is essential reading for an understanding of the development of cricket in the modern era, and the role that cricket has played in the hands of politicians, capitalists, administrators and cricketers themselves, in the reconstitution of a free South Africa.

Cricket, says Desai, echoing J M Coetzee, is the truth of life. In South Africa, cricket has not only been truth, illuminating the dynamics of political and social relations, but from an early date it has been a driver behind key political decisions shaping South African society itself. Black fast bowler 'Krum' Hendricks was famously omitted from the first South African tour in 1894 on the say so of Cecil Rhodes and Joey Milton, Rhodes's Private Secretary and cricketerfixer. Hendricks fought tirelessly for another decade to have his talent recognised by the cricketing establishment only to have the door slammed on 
him time and again by those who refused to countenance any suggestion that blacks were acceptable on equal terms within a white-defined South Africa.

The catalytic effect of this decision in the 1890s, building on socio-economic class structures at the Cape, the demands of the mining economy, and then the pressure for Union after the South African war, meant that the next 50 years of black cricket saw an ongoing struggle on patches of scrub land throughout the country. It was here that all those not classified as 'European' sought to build communities and play the game they loved, in the face of racist legislation, restricted opportunities, segregationist ideology and police brutality. The hidden history of cricket goes way beyond a game into the nature of South Africa itself and the evolution of its society. Ultimately, from the 1950s onwards, cricket became a key battleground for overthrowing the racist apartheid structure or retaining the essence of racist white South Africa, as international engagement ended and formal isolation began.

The rogue cricket tours during the isolation period were not just part of the last flickering of apartheid's light. As Desai notes, they did far more than uplift white morale, they encouraged South African administrators 'who knew how to dissemble and to window dress, who could talk development while enriching elite players, who were happy to cosy up to government and who, above all, understood the power of the cheque book' to transfer this modus operandi into the period of democratic transition.

Ali Bacher's remarkable career encompassed being SA's apartheid cricket captain, organiser of rebel tours (and a 'transformation' programme that supported the 1980s status quo), cricket development advocate, administrator for the ANC's sports programme, and confidant of Hansie Cronje. The power of money, of rebranding and the reformative ANC strategy, shaped change so that much in effect remained the same. Bacher's curious mixture of naivety and slipperiness, idealism and pragmatism (can he really have been unaware of the brutalities of apartheid despite working as a junior doctor in Baragwanath Hospital? Why did he not support the Newlands walk off?) cast a long shadow, and was a major contributor in destroying SACBOC cricket.

But Bacher was not the only witting or unwitting servant of apartheid. Others including Boycott, Gooch, Gatting, Kim Hughes and a cast of hundreds failed to notice the antagonism of the local population, the refusal of black staff to serve them in hotels, and in the end held their noses, or threw in their lot, with the white braaivleis culture. Perhaps inevitably, it was blacks, particularly the West Indies players on the rogue tours, who suffered most. Richard 'Germs' Austin ended up a homeless derelict on the streets of his native Kingston, and David Murray a drug' addict in Barbados, endlessly accused of selling his soul. Meanwhile Mike Gatting, 
Nelson-like in turning a blind eye in 1990, 25 years later became President of the MCC. In a story of so much pain and injustice, we should be angry but we should not be surprised.

For Desai, the real villain of the piece is the ANC's economic policy itself. He quotes Ronnie Kasrils's description of the ANC's Faustian pact, where an IMF Ioan was chosen with strings attached that precluded a radical economic agenda. Down the line, the ANC failed to deliver an accelerated redistributive process, and the Growth, Employment and Redistribution programme (GEAR) effectively locked down relations of poverty and inequality and this was paralleled by a failure to deliver the kind of massive cricket redevelopment programme needed to turn South African cricketers into real representatives of their country. Desai links the victory of the top down 'reformative' programme over 'transformative' bottom up initiatives and describes how a new language emerged in the 1990s to justify 'all white' cricket teams with the idea that new black players would emerge as the money flowing from international competitiveness trickled down through development programmes.

As cricket unity was consolidated at the top level, black clubs suffered, unable to compete with the facilities of their white counterparts, and amalgamated, leaving thousands of black cricketing enthusiasts in the cold. A new vision was needed, and this, initially based on the Transformation Monitoring Committee, focused on bottom up cricket engagement through black African communities. Greater black engagement resulted but speedy grass roots transformation was ultimately subject to societal transition itself.

The trickle down strategy and the relative slowness of black impact at international level when faced with a population anxious for new heroes, forced the introduction of quotas/targets, making race a key factor in team selection. Desai suggests the possibility that the quotas forced selectors to divest themselves of prejudicial thinking, allowing for the recognition of performers such as Gibbs and particularly Ntini. But quotas may have had almost no impact at national level apart from undercutting the position of the players it was designed to support. Overt or covert selection along racial lines made it almost impossible for players of colour to have confidence in their abilities (as the case of Charl Langeveldt demonstrates) whatever their potential and talent. And if they struggled to find confidence, it was difficult for their teammates to provide full support. The cricketing public, whether or not they were prejudiced against such selections in the first place, also had little faith in black players and the cycle of racism as a key element in South African cricket continued.

Only a player as good as Kagiso Rabada, the youngest bowler ever to top the ICC world rankings, can be viewed without scepticism. The recent emergence 
of Lungi Ngidi may also help break the mould. But the difficulties that Temba Bavuma, on the other hand, has had to deal with despite his obvious talent are exacerbated by the insecurity he has faced. Desai rightly argues that players such as Bavuma need a clear commitment to their position in the side to enable their talent to flow. But paradoxically the recent dropping of Bavuma for De Villiers may also have the opposite effect - it may make it clear that when he is selected it is on merit alone - ending the taint of 'quota'-based choices within the Proteas.

We should never lose sight of the class issue. Rabada, Bavuma and Ngidi came from South Africa's elite schools, where they were able to hone their natural talents, enjoying the advantages taken for granted by South Africa's white superstars. So where does this leave the grassroots programme and the future of SA cricket? Do we continue to rely on the elite schools and their scholarship programmes, effectively extending a white cricketing middle class to include talented Africans (and working class whites)? Is cricket inevitably a game of the privileged classes, or should we be concentrating on the underclass of black urban and rural workers at grassroots level? Perhaps the answer is that we need to attack this from both sides, but that we shouldn't confuse the two approaches.

A real development programme needs more than just coaches and facilities, scarce as these are. As Mike Proctor movingly described, when he took on the job of working with Ottawa School outside Durban, it was food not cricket that the pupils needed, and food availability drove cricket participation.

In the end, as Desai suggests, we are left with what the ANC itself has called the silent shift from transformative politics to palace politics. A new ANC President may inspire hope but cricket in South Africa will always reflect the political economy, and continue to ask the reformative/transformative question. Hassan Howa's 'no normal sport in an abnormal society' still resonates when economic and social disadvantage remain the basic condition of the vast majority of the population. 